\title{
Analisis hasil belajar tematik siswa dengan strategi pembelajaran berbasis masalah di sekolah dasar
}

\author{
Fitri Hayati $^{\left.1^{*}\right)}$, Firman Firman ${ }^{2}$, Desyandri Desyandri ${ }^{3}$ \\ ${ }^{123}$ Universitas Negeri Padang
}

\section{Article Info \\ Article history: \\ Received Jan $27^{\text {th }}, 2021$ \\ Revised Feb 24 ${ }^{\text {th }}, 2021$ \\ Accepted Feb 19 $9^{\text {th }}, 2021$}

\section{Keyword:}

Hasil belajar

Ilmu pengetahuan alam

\begin{abstract}
ABSTRAK
Pelaksanaan penelitian ini bertujuan untuk menganalisis peningkatan hasil belajar siswa dalam pembelajaran tematik materi tema ekosistem dengan menerapkan strategi Pembelajaran Berbasis Masalah di Kelas V SD. Penelitian ini merupakan Penelitian Tindakan Kelas (research action). Dalam penelitian ini digunakan gabungan pendekatan kualitatif dan kuantitatif. Subjek dalam penelitian ini adalah seluruh siswa kelas V pada Tahun Ajaran 2019/2020. Perolehan data pada siklus 1 tentang hasil belajar siswa diperoleh skor capaian keseluruhan siswa pada siklus I yaitu 71,8 atau $72 \%$. Perolehan nilai pada siklus II terhadap ranah kognitif dengan rata-rata 83,91, aspek afektif 82,5 dan aspek psikomotor 84,2, rata-rata nilai dari keseluruhan aspek adalah 83,53. Pada siklus II pertemuan II diperoleh nilai rata-rata aspek kognitif 94,19, aspek afektif 93,7, dan aspek psikomotor 93,3 sehingga rata-rata dari ketiga aspek tersebut adalah 93,73. Dengan demikian dapat disimpulkan bahwa hasil belajar siswa dapat meningkat dengan penerapan strategi Pembelajaran Berbasis Masalah (Problem Based Learning) dalam pembelajaran tema ekosistem muatan IPA kelas V SD.
\end{abstract}

(C) 2021 The Authors. Published by IICET

This is an open access article under the CC BY-NC-SA license (https://creativecommons.org/licenses/by-nc-sa/4.0)

\section{Corresponding Author:}

Fitri Hayati,

Universitas Negeri Padang

Email: fitrihayati927@gmail.com

\section{Pendahuluan}

Efisiensi dan efektifitas dalam pembelajaran perlu ditingkatkan pada semua aspek, materi dan muatan pembelajaran yang tersedia dalam kurikulum. Memperbaiki proses pembelajaran dapat meningkatkan mutu pendidikan yang akan diikuti oleh peningkatan hasil belajar pada semua aspek pembelajaran tematik. Muatan pembelajaran tematik kelas tinggi dalam Kurikulum 2013 salah satunya adalah muatan Ilmu Pengetahuan Alam (IPA).

Sains dapat diartikan sebagai bidang kajian ilmu yang mempelajaari kejadian atau peristiwa yang berada di kehidupan nyata siswa dan dapat diamati siswa melalui peristiwa alam (Yulianti, 2017). IPA membahas semua peristiwa dan gejala alam secara keseluruhan baik fisik maupun secara biologi, atau ilmu yang mempelajari alam semesta beserta gejala-gejalanya. Menurut (Fauzan dkk., 2017) bahwa sains merupakan rentetan konsep yang berhubungan atau melengkapi satu sama lain berdasarkan hasil eksperimen dan observasi. Pembelajaran Ilmu Pengetahuan Alam melatih siswa untuk berfikir kritis dan objektif, kemudian siswa diharapkan dapat menyatakan pendapat setelah mereka mengamati objek dan juga diharapkan dapat mengatasi masalah dalam menghadapi kenyataan di alam. Disamping itu dalam pembelajaran IPA siswa difasilitasi untuk mengeksplorasi pemahaman tentang alam dan lingkungannya lebih mendalam (Fitria, 2017). 
Kenyataan yang terjadi dilapangan justru sebaliknya. Hal ini berdasarkan wawancara dan pengamatan dengan beberapa orang guru SD Negeri 17 Pasar Baru Durian, Kota Sawahlunto 12 September 2019 ditemukan beberapa hal sebagai berikut: ; (a) rendahnya hasil belajar siswa dan minat belajar siswag serta kurang percaya diri; (b) guru terlalu dominan dan monoton dalam proses pembelajaran, siswa kurang diberikan kesempatan untuk menemukan permasalahan serta mencari solusi yang tepat; (c) guru kurang mampu menanamkan konsep mengenai suatu materi pelajaran, kurang terampil dalam menggunakan media sehingga proses pembelajaran terasa kaku. (d) siswa merasa tidak tertantang untuk berpikir kritis karena tidak diberikan suatu permasalahan terkait materi pelajaran; (e) siswa kurang diberikan pengalaman dan permasalahan yang terkait dengan lingkungan sekitarnya; (f) siswa jarang diberikan kesempatan untuk mengalami sendiri suatu pembelajaran atau jarang diajak untuk melakukan suatu percobaan untuk menemukan solusi suatu permasalahan dan motivasi sebelum atau saaat pembelajaran.

Permasalahan di atas harus segera ditindaklanjuti agar peningkatan hasil belajar siswa terlihat secara signifikan. Langkah yang dapat dilakukan adalah memperbaiki proses pembelajaran dengan pemilihan strategi yang tepat dan sesaui merupakan kunci kesuksesan atau keberhasilan dalam mencapai tujuan. Salah satu strategi yang dianggap ampuh mengatasi permasalahan yang dikemukakan dalam pembelajaran IPA adalah strategi Pembelajaran Berbasis Masalah, karena startegi ini dapat membangkitkan motivasi siswa. Strategi ini memfasilitasi siswa untuk menemukan suatu permasalahan dan solusinya sehingga tertantang untuk belajar.

Lee (dala Taufik \& Muhammadi, 2011) berpendapat strategi Pembelajaran Berbasis Masalah merupakan proses belajar mengajar dengan membutuhkan keterampilan berpikir untuk menghubungan pengetahuan sebelumnya dengan konsep baru dalam tuntutan situasi cerita baru atau konsep baru. Strategi Pembelajaran Berbasis Masalah memaicu penggunaan berbagai kecerdasan untuk menghadapi persoalan baru dan peristiwa yang baru ditemui (Tan dalam Rusman, 2011). Oleh karena itu, peneliti menggunakan strategi ini berdasarkan tahap-tahapnya agar siswa dapat menguasai pembelajaran dan memperoleh nilai yang memuaskan dalam pembelajaran tematik dengan materi rantai makanan dan jaring-jaring makanan

Sanjaya (dalam Nuraini \& Kristin, 2017) menyatakan tahapan pembelajaran dengan strategi Pembelajaran Berbasis Masalah antara lain:(1)menyadari suatu permasalahan, diawal kegiatan proses belajar mengajar siswa menemukan permasalahan yang harus diselesaikan;(2) masalah yang ditemukan dirumuskan dengan spesifik;(3) merumuskan hipotesis, siswa dapat;(4) mengumpulkan data yang relevan, dan memilihnya;(5) menguji hipotesis, pada tahapan ini siswa mengolah data dan menemukan hubungannya dengan permasalahan yang ada; (6) memilih solusi masalah, pada tahapan ini siswa bebas memilih solusi permasalahan yang sesuai dan cocok dengan sebab akibat dari masalah yang ditemukan. Tujuan utama penelitian ini dilakukan adalah untuk menganaliss hasil belajar siswa pada pembelajaran tematik sub tema komponen ekosistem kelas V SDN 17 Pasar Baru Durian Sawahlunto. Maka, rumusan masalah dalam penelitian ini yaitu bagaimanakah analisis peningkatan hasil belajar siswa pada pembelajaran tematik tema ekosistem dengan strategi pembelajaran berbasis masalah di sekolah dasar

\section{Metode}

Tempat pelaksanaan penelitian adalah di SD Negeri 17 Pasar Baru Durian, Kota Sawahlunto. Semua siswa kelas V SD Negeri 17 Pasar Baru Durian, Kota Sawahlunto dijadikan subjek dalam penelitian ini. Jenis penelitian yang digunakan yaitu action research/penelitian tindakan kelas (PTK) dengan gabungan pendekatan kualitatif dan kuantitatif. Penelitian kualitatif digunakan dalam perencanaan, pelaksanaan, dan penilaian proses kegiatan pembelajaran dalam menciptakan pembelajaran yang sesuai dan dapat memfasilitasi siswa untuk memiliki penguasaan atau pemahaman materi yang tinggi. Sementara itu, pendekatan kuantitatif menggunakan analisis statistika dalam pengolahan data berupa angka-angka perolehan nilai siswa.

Penelitian dilaksanakan dalam dua tahapan siklus dengan dua pertemuan pada setiap siklus tersebut. Masing-masing siklus meliputi tahap perencanaan, pelaksanaan, pengamatan, dan refleksi. Guru dan siswa dijadikan subjek penelitian ini. Observasi dan tes dilakukan dalam pengumpulan data yang dibutuhkan selama penelitian. Sedangkan RPP dan lembar penilaiannya (APKG 1), dan lembaran tes serta kunci jawabannya dipakai sebagai alat pengukur persiapan dan pelaksanaan pembelajaran oleh guru dan juga mengukur ketercapaian tujuan pembelajaran dalam aspek hasil belajar oleh siswa.

Dalam penelitian ini analisis data kualitatif digunakan untuk mendeskripsikan dan menginterpretasikan data serta penarikan kesimpulan. analisis data kuantitatif digunakan untuk persentase data sesuai yang dikemukakan menurut (Purwanto, 2011) 


\section{Hasil dan Pembahasan}

\section{Perencanaan Pembelajaran}

Rancangan pembelajaran tematik di kelas $\mathrm{V}$ pada tema 5 dengan menerapkan strategi Pembelajaran Berbasis Masalah (Problem Based Learning) berupa Rencana Pelaksanaan Pembelajaran (RPP). Penyususan RPP ini didasarkan salah satu kegiatan pembelajaran pada program pembelajaran semester I sesuai topik pembelajaran yang telah ditentukan peneliti yakni materi tema 5 yaitu Ekosistem dengan muatan IPA. RPP ini dirancang sesuai aturan dan arahan dosen pembimbing serta masukan teman sejawat agar RPP yang dihasilkan memilki kualitas yang baik dalam setiap komponennya.

Penilaian RPP pada siklus I pertemuan I yaitu 71,87,\% (C), dan pada siklus I pertemuan II mengalami peningkatan menjadi $75 \%$ (C). Penilaian RPP pada pertemuan I siklus II, menunjukkan nilai $84,38 \%$ (B) dan pada pertemuan II siklus II menunjukkan nilai 90,63\% (SB).

Rencana Pelaksanaan Pembelajaran (RPP) pada hakikatnya gambaran tahapan pembelajaran yang dijabarkan berdasarkan silabus untuk mencapai tujuan pembeljaaran dalam tiap standar kompetensi, Kunandar (2007). Komponen rancangan kegiatan pembelajaran yang disusun guru antara lain: (1) Standar Kompetensi, (2) kompetensi Dasar, (3) Indikator, (4) Tujuan Pembelajaran, (5) Materi Pokok dan Uraian Materi, (6) Langkah pembelajaran, (7) Media dan Sumber, (8) Evaluasi. Standar Kompetensi dan Kompetensi Dasar diturunkan substansi Kurikulum 2013 Kelas V Sekolah Dasar.

Pada materi pertemuan I siklus I yang dipelajari adalah hubungan antar komponen ekosistem mendapat perolehan nilai 71,87, sedangkan Pada siklus pertama memperoleh nilai 75, predikat cukup. Sedangkan pada perencanaan pertemuan I pada tahapan siklus materi yang dipelajari tentang hubungan antar komponen ekosistem, memperoleh nilai 84,38. Sementara itu pada pertemuan II siklus II materi yang dipelajari yaitu rantai makanan dan jaring-jaring makanan memperoleh nilai 90,6. Perencanaan pada siklus I masih diperlukan perbaikan perencanaan yang lebih terarah dan terukur. Hasil penilaian diperoleh persentase 73,5\% (C), pada siklus II terdapat peningkatan yaitu dengan perolehan persentase $87,5 \%$.

\section{Pelaksanaan Pembelajaran}

Pengamatan terhadap pelaksanaan pembelajaran tematik di kelas V pada Tema 5 dengan muatan IPA komponen ekosistem yakni rantai makananan dan jaring-jaring makanan terdapat pada sub tema 3 tema 5 dengan menerapkan strategi Pembelajaran Berbasis Masalah dilaksanakan berdasarkan siklus penelitian yang dirancang setiap siklus penelitian terdiri dari dua kali kegiatan pembelajaran. pada tanggal 21 November 2019 dilaksanakan siklus I pertemuan I dan tanggal 22 November 2019 pertemuan II. Selanjutnya, pada tanggal 29 November 2019 dilaksanakan pertemuan I siklus II pertemuan I dan pertemuan II dilaksanakan pada tanggal 30 November 2019.

Aspek guru pada pertemuan I siklus I diperoleh persentase 79,17\% kriteria cukup dan dari aspek siswa $70,83 \%$ dengan kriteria cukup. Sementara itu aspek guru dan siswa bertuturut pada pertemuan II diperoleh persentase sebesar $79,17 \%$ dan $75 \%$ dengan kriteria cukup. Terdapat peningkatan pada pertemuan I pada siklus II aspek guru diperoleh persentase $83,33 \%$ dan aspek siswa $79,15 \%$ dan pada pertemuan II dari aspek guru guru diperoleh persentase 91,67\%, dan dari aspek siswa 91,67\%. Data-data tersebut menunjukkan peningkatan pelaksanaan kegiatan pembelajaran tematik yang berdasarkan strategi yang digunakan dalam penelitian dapat terlaksana dengan baik serta sesuai dengan perencanaan.

Pelaksanaan pembelajaran temtatik tema 5 sub tema 3 dengan fokus materi rantai makanan dan jaringjaring makanan sesuai sintak strategi pembelajaran yang dipilih oleh peneliti dalam penyelesaian masalah pembelajaran pada penelitian ini. Dalam pembelajaran tematik semua aspek kompetensi dari berbagai muatan pembelajaran digabungkan menjadi suatu kesatuan dalam rangkaian proses pembelajarran terpadu (Asmelia \& Fitria, 2020). (Fitria dkk., 2018) juga berpendapat bahwasanya dalam pembelajaran tematik guru sebagai fasilitator hendaknya bisa mengakomodasikan siswa agar bisa berpartisipasi aktif dalam kegiatan pembelajaran. Maka dari itu, proses pembelajaran diamati dari aspek guru dan siswa. Masih banyak terdapat kekurangan dalam pelaksanaan pembelajaran, dimana pelaksanaan setiap tahapan strategi Pembelajaran Berbasis Masalah belum terlaksana dengan baik pada siklus I. Guru kurang memberikan petunjuk, arahan dan bimbingan kepada siswa selama proses pembelajaran, seperti kurang memberikan petunjuk sebelum siswa mengerjakan percobaan. Di samping itu, dalam pembelajaran siswa kurang aktif dan masih malu-malu mengemukakan jawabannya serta kurang berani menanggapi pendapat temannya. Rendahnya stimulus gairah belajar siswa oleh guru dalam kegiatan pembelajaran berlangsung agar siswa aktif dalam diskusi serta di dalam seluruh kegiatan pembelajaran. Dengan penerapan Pembelajaran Berbasis Masalah dapat menguatkan pemahaman konten belajar dan memiliki pengembangan kecakapan penentuan penyelesaian masalah, Rusman (2011). 
Guru perlu mrngkondisikan kelas dan menumbuhkan keterlibatan siswa dengan maksimal untuk mengikuti pembelajaran dari awal kegiatan sampai pembelajaran berakhir. Firman (2019) motivasi yang dimiliki oleh siswa akan membantunya mencapai hasil pembelajaran yang baik. Oleh karena itu, motivasi sangat penting diberikan kepada siswa. Adapun hasil penilaian terhadap guru pada pelaksanaan pembelajaran di siklus pertama memperoleh persentase 79\%, sementara dari aspek kegiatan siswa pada siklus pertama memperoleh capaian $72,5 \%$ dengan kriteria $\mathrm{C}$.

Pada kegiatan siklus ke-dua guru mengadakan perbaikan pada pelaksanaan setiap langkah pembelajaran dan lebih memberikan motivasi, bimbingan dan arahan kepada siswa. Disamping itu, siswa sudah tidak malumalu lagi dan berani dalam mengemukakan jawabannya serta menanggapi jawaban temannya. Penilaian pelaksanaan pembelajaran pada siklus II ini dari apek guru diperoleh skor $87,5 \%$ dengan kriteria B dan dari kegiatan siswa diperoleh skor $85,42 \%$ dengan kriteria baik. Hal ini menunjukkan bahwa pelaksanaan pembelajaran tematik pada tema 5 yang menerapkan sintak strategi pembelajaran berbasis masalan telah dilaksanakan dengan baik.

\section{Hasil Belajar}

Penilaian capaian belajar siswa yang diolah mengacu pada ketiga ranah pembelajaran yaitu pengetahuan, sikap, dan keterampilan. Kemampuan siswa dalam mengerjakan soal-soal tes secara individu dijadikan penilaian terhdap aspek kognitif siswa. Sedangkan sikap siswa yang diamati selama proses pembelajaran dijadikan dasar dalam penilaian aspek afektif yaitu kedisiplinan, menghormati, dan keberanian. Selanjutnya, aspek psikomotor dinilai dari perbuatan siswa dalam melakukan percobaan dan diskusi kelompok meliputi kecakapan menggunakan alat, keterampilan melakukan percobaan dan menyampaikan hasil percobaan.

Pada pelaksanaan pertemuan I dalam tahapan siklus I diperoleh hasil penilaian dari aspek kognitif dengan rata-rata 73 dengan kriteria cukup (C), aspek afektif 63,4 dengan kriteria kurang (K) dan aspek psikomotor 66,2 dengan kriteria kurang (K) sehingga dari ketiga aspek tersebut diperoleh rata-rata 67,8 dengan kriteria kurang (K). Pada pertemuan kedua siklus penelitian ke pertama dicapai rata-rata nilai hasil belajar aspek kognitif 81,52 dengan kriteria baik (B), aspek afektif 73,33 kriteria cukup (C) dan aspek psikomotor 73 kriteria cukup (C), sehingga untuk ketiga aspek ini diperoleh rata-rata sebesar 72,5 kriteria cukup (C).

Pada kegiatan penelitian siklus pertama hasil belajar siswa dicapai dengan skor nilai keseluruhan siswa kegiatan siklus pertama yaitu 71,8 atau 72\% dengan kriteria cukup (C). Perolehan nilai pada siklus II terhadap ranah kognitif denganrata-rata 83,91 dengan kriteria baik (B), aspek afektif 82,5 kriteria baik dan aspek psikomotor 84,2, kriteria B, rata-rata nilai dari keseluruhan aspek adalah 83,53 kriteria B . perolehan rata-rata kegiatan pertemuan ke-dua dalam siklus kegiatan ke-dua aspek kognitif 94,19 kriteria sangat baik (B), aspek afektif 93,7 kriteria sangat baik (SB), dan aspek psikomotor 93,3 kriteria sangat baik (SB) sehingga perolehan rata-rata dari ketiga aspek tersebut adalah 93,73. Perolehan nilai keseluruhan siswa pada siklus kedua yaitu 88,6 atau 89\% dengan kriteria baik (B).Berdasarkan data di atas disimpulkan bahwa terdapat perolehan nilai yang baik oleh siswa sebagai indikasi hasil belajar siswa tersebut sudah menunjukkan peningkatan yang signifikan.

Keberhasilan belajar siswa akan ada jika mereka termotivasi serta aktif dalam pembelajaran, Pratama, dkk.(2019). Peningkatan capaian belajar siswa merujuk pada perubahan aspek kognitif, afektif dan psikomotoris sebagai hasil proses pembelajaran yang diikutinya (Maysarah dan Firman, 2018). Berdasarkan pendapat tersebut Ranah pembelajaran yang termasuk penilaian hasil belajar meliputi ranah pengetahuan, keterampilan, dan sikap. Perolehan nilai pada pertemuan pertama siklus pertama secara keseluruhan siswa 67,8 pada pertemuan II terjadi peningkatan dengan perolehan skor 75,77 . Dari hasil ini tampak masih banyak siswa yang kurang memahami materi perubahan sifat benda, sehingga dari keseluruhan siklus I diperoleh persentase nilai yaitu $72 \%$. Selanjutnya, berdasarkan analisis dari hasil penelitian pada siklus II, perolehan nilai untuk hasil pembelajaran oleh siswa terlihat naik dari siklus pertama. pada pertemuan I diperoleh ratarata 83,53 dan pada kegiatan pertemuan ke II naik menjadi 93,73. Apabila dilihat secara keseluruhan siklus II persentase $89 \%$.

Perolehan skor penilaian pada siklus II yang meningkat degan signifikan menunjukkan pelaksanaan tahaptahap strategi ini sudah terlaksana dengan optimal dan adanya keberhasilan guru dalam upaya meningkatkan hasil belajar siswa dalam pembelajaran tematik pada tema 5 materi rantai maknanan dan jaring-jaring makanan di kelas V SD Negeri 17 Pasar Baru Durian, Kota Sawahlunto.

\section{Simpulan}

Simpulan dari penelitian ini adalah adanya pengingkatan hasil belajar siswa pada pembelajaran tematik yang menerapkan strategi Pembelajara Berbasis Masalah yang sudah maksimal. Peningkatan terus terjadi pada 
setiap pertemuan kegiatan pembelajaran yang telah dirancang dan dilaksanakan. Hal ini dibuktikan dengan hasil penilaian capaian belajar siswa selalu meningkat pada tiap pertemuan kegaiatan pemeblajaran. Tidak hanya itu, penilaian rancangan pembelajaran terjadi peningkatan dengan perolehan skor 87,5. Penilaian terhadap pengamatan pelaksanaan pembelajaran juga mengalami peningkatan yaitu memperoleh skor 85,42 . Sedangkan untuk nilai capaian belajar siswa tentang pemahaman materi pembelajaran memperoleh skor 88,6. Dengan demikian, penerapan strategi Pembelajaran Berbasis Masalah (Problem Based Learning) efektif digunakan dalam meningkatkan hasil belajar siswa dalam pembelajaran IPA di kelas V SD Negeri 17 Pasar Baru Durian, Kota Sawahlunto. Oleh karena itu,Guru perlu melaksanakan setiap sintak dalam strategi ini dan melaksanakannya, sehingga tujuan pembelajaran dapat lebih maksimal dan dapat dilakukan secara berkesinambungan oleh sekolah.

\section{Referensi}

Arifin, Z. (2017). Evaluasi Pembelajaran. Bandung: PT Remaja Rosdakarya.

Arikunto, S. (2012). Penelitian Tindakan Kelas. Jakarta: Bumi Aksara.

Asmelia, S. P., \& Fitria, Y. (2020). Hubungan Motivasi Belajar dengan Hasil Belajar Siswa pada Pembelajaran Tematik di Kelas IV Sekolah dasar. Jurnal inovasi pembelajaran sd, 8.

Darhim, Prabawanto, S., \& Susilo, B. E. (2020). The effect of problem-based learning and mathematical problem posing in improving student's critical thinking skills. International Journal of Instruction, 13(4), 103-116.

Fauzan, m., gani, a., \& syukri, m. (2017). Penerapan Model Problem Based Learning Pada Pembelajaran Materi Sistem Tata Surya Untuk Meningkatkan Hasil Belajar Siswa. Jurnal Pendidikan Sains Indonesia, 05(01), 2735.

Fitria, Y. (2017). Efektivitas Capaian Kompetensi Belajar Siswa dalam Pembelajaran Sains di Sekolah dasar. Jurnal Inovasi Pendidikan dan Pembelajaran Sekolah Dasar, 1(c).

Fitria, Y., Eliyasni, R., \& Yukitama, R. (2018). Perubahan Belajar Sains Siswa Sekolah Dasar Pada Pembelajaran Terintegrasi (Terpadu) Melalui Model Discovery Learning. Jurnal Inovasi Pendidikan Dan Pembelajaran Sekolah Dasar, 2, 52-63.

Kunandar. (2011). Langkah Mudah Penelitian Kelas Sebagai Pengembangan Profesi Guru. Rajagrafindo Persada.

Nuraini, V., \& Kristin, F. (2017). Penggunaan Model Problem Based Learning (pbl) untuk Meningkatkan Hasil Belajar IPA siswa kelas 5 SD. 1(4), 369-379.

Pratama, F., Firman, \& Neviyarni. (2019). Pengaruh Motivasi Belajar Ipa Siswa Terhadap Hasil. Jurnal Ilmu Pendidikan, 1(3), 280-286.

Purwanto, N. (2009). Prinsip-Prinsip dan Teknik Evaluasi Pengajaran. PT Remaja Rosdakarya.

Rusman. (2011). Model Model Pembelajaran Mengembangkan Profesionalisme Guru. Rajawali Press.

Sudjana, N. (2011). PenilaianHasil Proses BelajarMengajar. Bandung: PT Remaja Rosdakarya.

Sugiyono. (2015). Metode Penelitian. Bandung: Alfabeta.

Taufik, T., \& Muhammadi. (2011). Mozaik Pembelajaran Inovatif. Sukabina Press.

Yaumi, M. (2016). Prinsip-Prinsip Desain Pembelajaran Disesuaikan dengan Kurikulum 2013. Jakarta: Prenadamedia Group.

Yulianti, Y. (2017). Literasi Sains Dalam Pembelajaran IPA. Jurnal Cakrawala Pendas, 3(2), 21-28. 